open to outstanding Native Americans, African Americans, and Latino(a)s planning to enroll in a doctoral program in the coming academic year. Funded fellowships are generally awarded only to students who are about to enter graduate school. Fellowships are not designed for advanced graduate students. Each year the application deadline falls on November 1 .

For more information, call or write APSA headquarters or visit the APSA web site at www.apsanet.org.

\section{Forty-Fifth Class of Congressional Fellows Begins 1997-98 Program}

As this year's class of 44 Congressional Fellows completed their orientation, they began an interviewing process occurring in a Congress that had undergone considerable turnover. Fellows divided their attention between offices which had long provided a solid learning experience for previous Fellows with the offices of Senators and Representatives who this year have for the first time hosted an APSA Congressional Fellow.

Among the veteran congressional offices again hosting a Congressional Fellow are: Senators Max S. Baucus (D-MT), Sam Brownback (R-KS), Alfonse D'Amato (R-NY), Richard Durbin (D-IL), James Jefford (RVT)'s Labor Committee, Edward Kennedy (D-MA)'s Judiciary Committee, Frank Lautenberg (D-NJ), and APSA Congressional Fellowship Program Advisory Committee member Richard Lugar (R-IN). Among those Senators or committees accepting Congressional Fellows for the first time include Senate Majority Leader Trent Lott (R-MS), Senator Pete Domenici (R-NM)'s Budget Committee, Senator John McCain (R-AZ), and Senator Olympia Snow (R-ME).

Fellows' assignments on the House side include long-time CFP supporters: Representatives Howard L. Berman (D-CA), APSA Congressional Fellowship Program Advisory Committee member David Price (DNC), Robert Ehrlich (R-MD), Sander Levin (D-MI), and Karen
Thurman (D-FL). Among Members of the House accepting their first Congressional Fellows were: Representatives Doug Bereuter (R-NE), Corrine Brown (D-FL), Michael Castle (R-DE), J. Dennis Hastert (R-IL), and Christopher Shays (RCT).

Senator Richard Lugar's observation about the APSA Congressional Fellows appears to be winning new adherents: "I am impressed by the skill and enthusiasm the Fellows display and I know of few other Washington mid-career programs whose standards for awarding fellowships come close to those set by the American Political Science Association."

Of special note was the Congressional Fellows' appreciation to our major funding benefactors including Program Advisory Board members Eugene Eidenberg (The Carlyle Group) and Gerald Kovach, representing the MCI Communications Corporation whose significant endowment provides a number of $\$ 30,000$ annual stipends for political science and journalist Fellows, and Advisory Committee member Robert Merry of Congressional Quarterly, Inc. which provides the Fellows with year-long subscriptions to Congressional Quarterly Weekly Reports and a reduced price on Politics in America.

For many Fellows the new world of networking became an important reality in the early weeks of the 1997-98 CFP year. This involved building new contacts among congressional staff during the interview process and, of particular importance, drawing upon the expertise and program loyalty among the some 1500 former Congressional Fellows, many of whom are scattered throughout the Washington, D.C. metropolitan area and who offered time and candid advice. One tangible example is the decision among the political scientists and international Fellows to collaborate on several publications this year including an article for $P S$.

\section{Census 2000 Update: Reporting Rules for Race and Ethnicity Set}

As reported in the October 30 , 1997 issue of the Federal Register, the Office of Management and Budget has adopted new rules for the collection of race and ethnicity information on government forms, including census forms.

According to the new rules, respondents will be allowed to check more than one category for "Race" and only one category for "Ethnicity." The choices for "Race" will be American Indian or Alaska Native, Asian, Black or African American, Native Hawaiian or Other Pacific Islander, and White. For "Ethnicity," respondents may choose either Hispanic or Latino or Not Hispanic or Latino. In announcing the new reporting rules and categories, OMB made it clear that "the categories represent a social-political construct designed for collecting data on the race and ethnicity of broad population groups in this country, and are not anthropologically or scientifically based."

Guidelines for tabulating data collected from respondents choosing more than one of the race categories have not yet been issued. The full text of the OMB Federal Register notice is available on line at http:// www.whitehouse.gov/WH/EOP/ OMB/html/fedreg.html.

\section{Affirmative Action Bans Have Unclear Impact on Minority Admissions}

A Science magazine survey of graduate admissions to a select group of science, engineering, and medical programs (Barringa 1997, $633-34)^{1}$, indicates that the effects of the two states' recently enacted bans on affirmative action by California and Texas have not had a clearly uniform negative impact.

While admissions of black and Hispanic students to most large, competitive programs at universities in both states have dropped, a number of the smaller programs registered smaller decreases. For instance, while none of the 14 African 
American applicants offered admission to UC-Berkeley's law school enrolled in 1997, UCLA and UCDavis actually admitted more minority students to their medical and life sciences programs in 1997 than they did in 1996.

Several reasons have been proposed for the varied impact of the affirmative action ban on minority admissions. First, decreases in minority admissions to Texas's publically funded institutions have been uniformly greater than at California's state universities because the statutory nature of Texas's ban prevented officials from following California's lead in using federal research training funds, which carry affirmative action requirements, to blunt the ban's impact. Also, officials in programs where minority admissions dropped have cited their inability to consider factors other than test scores (a measure on which white males consistently out-perform all other groups) before making decisions over whom to select for oncampus interviews and other later, more subjective consideration.

Perhaps the greatest reason underlying reported declines in admissions of black and Hispanic students is the steady decline in the numbers of applicants from these groups. Perhaps discouraged by recent anti-affirmative action policy decisions and court rulings, fewer minority students applied to all surveyed schools in 1997 than did so in 1996.

Officials at UCLA, one of only two surveyed schools which reported increases in minority admissions, attributed its surprising success in attracting black and Hispanic students to "the strong pull the campus has for minorities because it is in an urban center with a high minority population." While not enjoying UCLA's proposed geographic advantage, UC-Davis also admitted more minority students in 1997 than in 1996 because the small size of its graduate programs allowed officials to evaluate each applicant more thoroughly and subjectively than officials at institutions with larger programs.

While the impact affirmative action bans will have on minority applications or admissions to graduate programs is not yet clear, officials at all surveyed schools have already developed and implemented recruiting programs designed to attract minority applicants. Notable among these are several schools' efforts to target historically black colleges while recruiting students, and the combined, cooperative B.S./M.D. program Baylor University sponsors with the University of Houston and University of Texas-Pan America.

1. Data on numbers of applicants and admission were obtained from UC-Berkeley, UC-Los Angeles, UCDavis, UC-San Diego, UC-Irvine, UT-Austin, UT-Southwestern Medical School, and Baylor College of Medicine.

\section{Washington Insider}

- Federal agencies are making their statistical data more accessible and easy to use by putting them on the Internet. Peter Syverson, in an analysis published in the September 1997 issue of the CGS Communicator, gives high marks to the Bureau of the Census (http://www.census.gov/), National Center for Education Statistics (http://www.ed.gov/NCES/), and National Science Foundation (http:// www.nsf.gov/) for their efforts to provide full and productive access to their databases. Other federal statistics can be accessed at the Fedstats web site (http://www.fedstats.gov/).

- On November 9,1997, the Senate voted unanimously to confirm Bill Ferris as the next Chairman of the National Endowment for the Humanities. Ferris, who holds a $\mathrm{Ph}$. D. in folklore from the University of Pennsylvania and is currently the director of the Center for the Study of Southern Culture at the University of Mississippi, was confirmed without a hearing because there was no opposition to his appointment.

- Senators Phil Gramm (R-TX) and Joseph Liberman (D-CT) are co-sponsors of the National Research Investment Act (S. 1305), which calls for a doubling of the federal government's investment in research over the next ten years. Current spending on nondefense research accounts for $1.9 \%$ of the federal budget, down from $5.7 \%$ of the federal budget in 1965 . The bill received the endorsement of 106 scientific societies, who issued a statement titled "A Decade of Investment" calling specifically for more support of transportation and sustainable energy research. According to statistics reported in the December 1997 issue of Science and Technology in Congress Update, federal expenditures on nondefense R\&D will increase by 5.4\% in FY 1998.

- The House Science Committee, chaired by F. James Sesenbrenner (R-WI), launched a year-long review of the federal government's long-range science and technology policy in October 1997. The last such review was conducted twelve years ago, before the end of the Cold War, the recent decline in federal research funding, and the growth of the Internet. 